\title{
RELATIONSHIP OF WATER AND WATER RESERVOIRS WITH THE PRESENCE OF AEDES AEGYPTI LARVAE IN PUUWATU PUBLIC HEALTH CENTER WORKING AREA KENDARI CITY
}

\author{
Titi Saparina $\mathbf{L}^{\mathbf{1}}$, Noviati ${ }^{\mathbf{2}}$ \\ ${ }^{1,2}$ Departement Of Publich Health Stikes Mandala Waluya Kendari, Southeast Sulawesi \\ Province, Indonesia
}

Corresponding Author: Titi Saparina

Email : titisaparina.stikesmw@ gmail.com

\begin{abstract}
Background: Aedes aegypti mosquitoes like to put their eggs in clean water so it is necessary to pay attention to the condition of the shelter of the water to always be closed because the water reservoir is in a closed condition it is less likely for the larvae to breed. Based on observation of 5 patient's house got mosquito larvae at water reservoir, other than that water reservoir left open and water quality slippery. This study aims to determine the relationship between water and aqueduct collection in the presence of Aedes aegypti larvae in the Work Area of Puuwatu Health Centre inKendari.

Methods:This type of research is a quantitative research with cross sectional study approach. The population is 265 and the sample is 72 respondents using random sampling technique Results:The results in this study indicate that the statistical water storage test results $\mathrm{X}^{2}$ count $36.217>X^{2}$ table 3.841 and water channel value $X^{2}$ count $16,774>X^{2}$ table 3,841. So it is concluded that there is a connection of water reservoirs and waterways with the presence of Aedes aegypti larvae in the Work Area of Puuwatu Health Centre in Kendari.

Conclusion: Suggested to the family should pay attention to environmental sanitation that can provide breeding place mosquito larvae breeding such as water and water ditch. In addition, the family must adjust the area of the house with the number of occupants in the house.
\end{abstract}

Keywords : Water Shelter, Water Channel, Mosquito larvae 


\section{INTRODUCTION}

The public health center is as one of the first-level health service facilities has an importantrole in service and disease prevention (1). Dengue Hemorrhagic Fever is a disease that is a public health problem because the impact is not only limited to economic impacts but also from a social perspective. The impact from the social aspect in question is the loss experienced by someone suffering from DHF including one of his family, the loss can be in the form of a sense of discomfort, family panic, and even the death of family members who will later have an impact on the broader problem of low life expectancy (2).

Dengue fever is now endemic in more than 100 countries in Africa, America, the Eastern Mediterranean, Southeast Asia and the Western Pacific. America, Southeast Asia and the Western Pacific are the regions that have the most severe dengue epidemics in the world. The incidence of DHF has grown dramatically throughout the world in the past few decades. More than 2.5 billion people or more than $40 \%$ of the world's population are at risk of suffering from DHF. WHO estimates that currently there may be 50-100,000,000 dengue infections worldwide each year and an estimated 500,000 cases of DHF require hospitalization each year, most of which are children with $2.5 \%$ deaths (3)

The number of patients reported in Indonesia in 2012 was 90,245 cases with 816 deaths $(I R=37.37$ per 100,000 population and CFR $=0.90 \%$ ). The highest number of DHF cases and DHF deaths per province in 2012 was in West Java Province which was 19,663 cases and 167 deaths. The DHF morbidity rate per province in 2012 was $<53$ per 100,000 population. There are 11 provinces that have a DBD morbidity rate above the national target in 2012, namely the provinces of Central Sulawesi, Bangka Belitung, Jambi, South Kalimantan, Central Java, Riau, East Java, West Kalimantan, Riau Islands and North Sulawesi.(4)

One form of DHF control carried out is by conducting larvae surveys aimed at breaking the chain of Aedes aegypti mosquito breeding which is a vector of dengue disease starting from larvae. The number of residents in a house can affect the availability of clean water that is used for daily needs, if the water needs of family members are insufficient it will have the potential for the community to collect water in reservoirs. The habit of storing water for household needs which includes barrel, whether made of clay, cement or ceramic as well as water reservoir drums that are not tight and if not supported by the implementation of $3 \mathrm{M}$, it will become a breeding ground for Aedes aegypti larvae (5) Aedes aegypti mosquitoes like to lay their eggs in clean water so it is necessary to pay attention to the conditions of the water reservoir whether closed or not because if the water reservoir is in a closed condition then it is less likely for larvae to breed. In addition, the number of water reservoirs also affects the existence of larvae because the more water reservoirs used by the community, the more potential places for larvae (6)

Based on the preliminary study of researchers obtained data, the number of dengue patients in 2014 was 6 cases, increased in 2015 to 30 cases, increased dramatically in 2016 to 265 cases. Based on observations of 5 houses, mosquito larvae were found in water reservoirs, besides that the water reservoir was left open and the water quality was slippery.

\section{METHOD}

This research is a quantitative research with cross sectional study approach. Cross Sectional Study or cross-sectional study is research conducted by measuring variables at one particular time. Measurement of variables in a cross sectional study is not limited to be precise at the same time, but it means that each subject is only subjected to one measurement, without follow-up. The population in this study is that all sufferers of DBD in 2016 amounted to 265 people. The sample is as a whole of 
Saparina L, T., \& Noviati.

DOI: 10.36566/ijhsrd/Vol2.Iss1/24

https://ijhsrd.com/index.php/ijhsrd

e- ISSN: 2715-4718

the subjects studied and is considered to be the entire population. The number of samples is calculated based on the sample formula for a small population of 72 people with a simple random sampling technique. The analytical method using bivariate analysis was conducted to test whether there was a relationship between the independent variable and the dependent variable using the chi-square statistical test (chi-square) using the significance limit $\alpha=0.05$.Presentation of data is done after the data is processed and presented in tabular form and presented accompanied by an explanation (narrated).(7)

\section{RESULT}

Based on the research results obtained from 72 research samples related to

respondent characteristics data related to age, education and job Table 1 shows that of the 72 respondents, the most was the age group 51- 60 years which amounted to 24 respondents (33.3\%), while the lowest was the age group $>60$ years amounted to 6 respondents $(8.3 \%)$. Of the 72 respondents the number of respondents based on the highest education was Elementary School Education, namely 28 people (39\%) while the smallest number of respondents was those with junior high school and senior secondary schools each of 13 people (18\%). Of the 72 respondents, the most respondents' jobs were farmers amounting to 34 people (47.2\%), and the least number of Civil Servants were 12 people (16.7\%).

Table 1. Characteristics of Respondents Age, Education and Job In Puuwatu Public Health Centre, in Kendari City in 2017

\begin{tabular}{|c|c|c|}
\hline Characteristics & $n(40)$ & $\%$ \\
\hline \multicolumn{3}{|l|}{ Age (Years) } \\
\hline $21-30$ & 8 & 11.1 \\
\hline $31-40$ & 14 & 19.5 \\
\hline $41-50$ & 20 & 27.8 \\
\hline $51-60$ & 24 & 33.3 \\
\hline$>60$ & 6 & 8.3 \\
\hline Total & 72 & 100 \\
\hline \multicolumn{3}{|l|}{ Education } \\
\hline Primary School & 28 & 39 \\
\hline Junior High School & 13 & 18 \\
\hline Senior High School & 13 & 18 \\
\hline College & 18 & 25.1 \\
\hline Total & 72 & 100 \\
\hline \multicolumn{3}{|l|}{ Job } \\
\hline Farmers & 34 & 47.2 \\
\hline Entrepreneur & 26 & 36.1 \\
\hline Civil servants & 12 & 16.7 \\
\hline Total & 46 & 100 \\
\hline
\end{tabular}

Source : Primary Data in2017

Table 2 shows that of the 72 respondents there were 29 respondents in the category of water reservoirs fulfilling the requirements there were 23 people $(31.9 \%)$ whose water reservoirs fulfilled the requirements for no larvae and 6 people $(8.3 \%)$ whose water reservoirs fulfilled the requirements but there were larvae. While of 
the 43 respondents in the category of water storage did not meet the requirements there were 4 people $(5.6 \%)$ whose water reservoirs did not meet the requirements but there were no larvae and 39 people (54.2\%) whose water storage did not meet the requirements for larvae.Based on the results of statistical tests with a calculated $X^{2}$ value of $33.292>$ $\mathrm{X}^{2}$ table 3.841 and $\varphi=0.709$, it can be concluded that $\mathrm{Ho}$ is rejected and $\mathrm{Ha}$ is accepted, thus there is a strong relationship with the presence of Aedes aegypti larvae in the Puuwatu Health Centre in Kendari City. Table 2 shows that out of 72 respondents, there were 22 respondents in the category of waterways fulfilling the requirements, there were 16 people $(22.2 \%)$ whose water channels met the requirements for no larvae

Table 2. The relationship of water reservoirs and water disposal to the presence of

Aedes aegypti larvae in the Work Area of Puuwatu Health Centre, Kendari City

\begin{tabular}{|c|c|c|c|c|c|c|c|}
\hline \multirow{3}{*}{ Variable } & \multicolumn{6}{|c|}{ The existence of Larvae } & \multirow{3}{*}{ Statistic Test } \\
\hline & \multicolumn{2}{|c|}{ There Is No } & \multicolumn{2}{|c|}{ There Is } & \multicolumn{2}{|c|}{ Total } & \\
\hline & $\mathrm{n}$ & $\%$ & $\mathrm{n}$ & $\%$ & $\mathrm{n}$ & $\%$ & \\
\hline \multicolumn{8}{|l|}{ Water reservoirs } \\
\hline Qualify & 23 & 31.9 & 6 & 8.3 & 29 & 40.3 & \multirow{3}{*}{$\begin{array}{l}X^{2} \text { count }: 33.292 \\
>X^{2} \text { Tab : } 3,841\end{array}$} \\
\hline Not eligible & 4 & 5.6 & 39 & 54.2 & 43 & 59.7 & \\
\hline Total & 27 & 37.5 & 45 & 62.5 & 72 & 100 & \\
\hline \multicolumn{8}{|l|}{ Drainage } \\
\hline Qualify & 16 & 22.2 & 6 & 8.3 & 22 & 30.6 & \multirow{3}{*}{$\begin{array}{l}X^{2} \text { count : } 14.679 \\
>X^{2} \text { Tab }: 3,841\end{array}$} \\
\hline Not eligible & 11 & 15.3 & 39 & 54.2 & 50 & 69.4 & \\
\hline Total & 27 & 37.5 & 45 & 62.5 & 72 & 100 & \\
\hline
\end{tabular}

Source : Primary Data 2017

\section{DISCUSSION}

Water Reservoir (TPA) consists of water storage in the house and water storage outside the home. Water reservoirs in the house are buckets / basins, barrels, jars and bathtubs / lavatories. Whereas the outdoor water reservoirs are cans of flower vases, fish ponds, and others. The existence of water reservoirs inside and outside the house is very influential on the presence or absence of Aedes aegypti larvae, even the water and 6 people $(8.3 \%)$ whose waterways fulfilled the requirements but there were larvae. While of the 50 respondents in the category of waterways not meeting the requirements there were 11 people $(15.3 \%)$ whose water channels did not meet the requirements but there were no larvae and 39 people $(54.2 \%)$ whose water channels did not meet the requirements for larvae.Based on the results of statistical tests with a calculated $\mathrm{X}^{2}$ value of $14.679>\mathrm{X}^{2}$ table 3.841 and $\varphi=0.483$, it can be concluded that Ho is rejected and Ha is accepted, thus there is a moderate correlation between the waterways and the presence of Aedes aegypti larvae in the Puuwatu Public Health Centre in Kendari City.

\author{
(1)
}


$(8.3 \%)$ whose water reservoirs fulfilled the requirements but there were larvae. While of the 43 respondents in the category of water storage did not meet the requirements there were 4 people (5.6\%) whose water reservoirs did not meet the requirements but there were no larvae and 39 people (54.2\%) whose water storage did not meet the requirements for larvae.Tubs are the most commonly found landfill larvae because almost every respondent's house has a bathtub, the community's habit of always filling water in the tub making it possible for water to stay for a long time and the community's habit to clean the tub when it looks dirty and just throwing away the water alone does not brush the surface of the tub making it possible for mosquito eggs to remain(9). The condition of closed and open landfill also affects the breeding of mosquito larvae. Hasyimi stated that one of the causes of water reservoirs became mosquito breeding grounds was that water reservoirs were not closed because if the water reservoirs used were open it would make it easier for Aedes aegypti mosquitoes to lay their eggs in the landfill.(10)

According to soegijanto, wastewater is a liquid that comes from households, industry, and other public places and usuallycontain ingredients or substances that can endanger human lifeas well as disrupting environmental sustainability (11)

The results showed that of 72 respondents there were 22 respondents in the category of waterways fulfilling the requirements there were 16 people $(22.2 \%)$ whose water channels met the requirements for no larvae and 6 people $(8.3 \%)$ whose waterways fulfilled the requirements but there were larvae. While of the 50 respondents in the category of waterways not fulfilling the requirements, there were 11 people $(15.3 \%)$ whose water channels did not meet the requirements but there were no larvae and 39 people (54.2\%) whose water channels did not meet the requirements for larvae. Domestic waste water comes from water used for bathing, washing clothes, and washing furniture, food ingredients, and so on. This water is often calledgray water which contains a lot of soap or detergent andmicroorganisms that cause various diseases. One cause of disease frommicroorganisms exists in wastewater. These microorganisms will be carried by vectors or insects to be infected with humans through food anddrinks. To break the chain of the disease needed a channeldisposal of wastewater (SPAL) households that meet the requirementshealth (12)

\section{CONCLUSION}

Based on the results of the study, it can be concluded that there is a relationship between income and access to the regular payment of contributions from SelfFinancing In Health Insurance members. it means that income and access are the causes of regular payment of contributions from Self-Finacing In Health Insurance members in Puuwatu Primary Health Care Centre, Kendari City.

\section{ACKNOWLEDGMENT}

The author conveys with utmost respect, expressing his unlimited thanks. A big thank you to the author also to the Mandala Waluya Foundation for giving us the opportunity to carry out the Education, research and community development especially in Puuwatu Health Centre. Thank you for your support, time and location during the study, and all parties for their motivation and support.

\section{REFERENCES}

1. Akbar MI. Akbar MI. Analysis of the needs of general practitioners in Public Health Centres using Helath Workload Method. Public Health of Indonesia. 2020;6(2):63-9.

2. Bustan, R. Factors relating to the implementation of DHF by the community in the working area of the Padang City Kuranji Public Health Center in 2007 Padang: FK Unand. 2007. (Indonesia) 
Saparina L, T., \& Noviati.

DOI: 10.36566/ijhsrd/Vol2.Iss1/24

https://ijhsrd.com/index.php/ijhsrd

3. Wisfer, Easy Ways to Beat Dengue Fever. Jakarta: Kompas Book Publisher. 2013. (Indonesia)

4. Department of Health RI. Behavior and Life Cycle of Aedes Aegypti Mosquito is very important to know in carrying out activities to eradicate mosquito nests, including periodic larvae monitoring. Jakarta: Ministry of Health Republic of Indonesia. 2004. (Indonesia)

5. Department of Health RI. Jumantik Monitor (Jumantik) One of the Roles of Community Participation in the Management of Dengue Hemorrhagic Fever (DHF). 2004. (Indonesia)

6. Suroso Dengue Hemorrhagic Fever. Situation and Eradication Program in Indonesia Seminar and Workshop on Various Aspects of Dengue and its Countermeasures. Depok: UI. 2012. (Indonesia)

7. Sugiono. Combination Research Methods. Bandung: Alfabeta. 2016. (Indonesia)

8. Department of Health RI. Instructions on the Implementation of the Eradication of Dengue Mosquito Nest (PSN-DBD) by the Monitors Monitors (Jumantik). Jakarta: DG PPM-PLP. 2004. (Indonesia)

9. Department of Health RI. Behavior and Life Cycle of Aedes Aegypti Mosquito is very important to know in carrying out activities to eradicate mosquito nests, including periodic larvae monitoring. Jakarta: Ministry of Health Republic of Indonesia. 2004. (Indonesia)

10. Erniwati. Stop Dengue Hemorrhagic Fever. Bogor. Cita Insan Madani. 2014. (Indonesia)

11. Wisfer, Easy Ways to Beat Dengue Fever. Jakarta: Kompas Book Publisher. 2013. (Indonesia)

12. Gilot, Tria Hasbi Akbar. Health Promotion Media for Dengue Fever Tropical Disease by the Surabaya. 2005. (Indonesia)

Indonesian Journal Of Health Sciences Research and Development 